\title{
Attar of Nishapur's Seven Valleys and the Stages of Human Cravings from a Psychological Perspective
}

\author{
Ayfer Summermatter ${ }^{1}$ \\ Marmara University
}

\begin{abstract}
This article examines the search for Truth and the journey of existence as explained metaphorically in the works of Farid ud-Din Attar by blending Sufi understanding and a contemporary psychological perspective. It attempts to associate and review people's characteristics, life styles, cognitive structures, existential journeys, and processes of self-realization through the Sufi views in Attar's stories. The Valleys of Quest, Love, Understanding, Independence and Detachment, Unity, Astonishment and Bewilderment, and Deprivation and Death that occur in Mantiq al-Tayr (The Conference of the Birds) are basically accepted through interpretation as the stages of human desires along with the characteristics that are required to transition from these valleys. This research also benefitted by interpreting other works by Attar, the IlahiNama (Book of God) and Asrar-Nama (Book of Mysteries).
\end{abstract}

\section{Keywords}

Attar $\bullet$ The seven valleys $\bullet$ Stages of human desire $\bullet$ Psychological examination $\bullet$ Personality

- Self-development

Psikoloji Perspektifinden Ferîdüddîn Attâr 'in Yedi Vadisi ve Nefis Mertebelerinin İncelenmesi

Öz

$\mathrm{Bu}$ makalede Attâr'ın eserlerinde metaforik olarak anlattı̆̆ı Hakk'ı arayış ve varoluşsal yolculuk tasavvuf anlayışı ve günümüz psikoloji perspektifi harmanlanarak incelenmiştir. Bu incelemede Attâr’’n hikâyelerindeki tasavvuf görüşleri ile insanın karakter özellikleri, yaşam tarzı, bilişsel yapısı, varoluşsal yolculuğu ve kendini gerçekleştirme süreci ilişkilendirilmiş ve yorumlanmaya çalışılmıştır. Yorumlama yapılırken Mantık Al-Tayr eserinde yer alan "istek, aşk, marifet, istiğna, tevhit, hayret ve fakr-u fena" isimli vadiler ve bu vadilerden geçiş için gerekli olan özellikler ile nefis mertebeleri temel olarak alınmıştır. Ayrıca yorumlama yapılırken Attâr’ın "Ilâhiname, Esrarname " eserlerinden de faydalanılmıștır.

Anahtar Kelimeler

Attâr • Yedi vadi • Nefis mertebeleri • Psikolojik inceleme • Kişilik • Kendini gerçekleştirme

1 Correspondence to: Ayfer Summermatter, PhD Student, Department of Educational Sciences, Marmara University, Göztepe Campus, Kadıköy, Istanbul 34722 Turkey. Email: ayfersummi@gmail.com

Citation: Summermatter, A. (2016). Attar of Nishapur's Seven Valleys and the stages of human cravings from a psychological perspective. Spiritual Psychology and Counseling, 1, 117-143. http://dx.doi.org/10.12738/spc.2016.2.0012 


\section{Attar's Life}

Attar, whose full name was Abu Hamid Farid ud-Din Muhammed bin Abu Bakr İbrahim of Nishapur (died ca. 1221[618 AH]), was a famous Iranian poet and Sufi mystic. He was most likely born between 1142 and 1145 (537-540 AH) in the last days of the Seljuk Empire in Khorasan. He took the moniker "Attar" for he worked in pharmaceuticals and medicine, becoming famous through this nickname. Information from sources about his childhood and youth is conflicting and inadequate. It is understood from his works, however, that he dealt with herbalism in his youth, while he also gathered knowledge, gained mystical information, and served various sheikhs. $\mathrm{He}$ is said to have read many books himself on prophets and saints, and continued to collect poems and stories related to Sufism for 39 years. Not much information is found about his family or close environment, apart from that he had lost his mother and father in adolescence (Şahinoğlu, 1991, pp. 95-98).

As understood from some of his poems and information from sources, Attar from a young age made many trips, especially after giving himself to mysticism; he returned to Nishapur after his travels and took to seclusion there. At the end of this life of seclusion, which continued for many years, he was killed in Nishapur by the Mongols while fairly old (Şahinoğlu, 1991, pp. 95-98).

\section{Analysis of Mysticism in Attar's Works}

Attar, who had contributed many works throughout his life, and affected authors and people of the Sufi faith who came after him, gave importance to understanding the oneness and uniqueness of the body. Tawheed (oneness) means to coalesce. According to Sufis, tawheed is to neither know nor acknowledge an existence apart from God; it is knowing that all is not in God's being but exists through God's being (Cebecioğlu, 2005; Gölpınarl1, 1969). Only the body that exists in the belief of the body's uniqueness is absolute. All power is in it. God is seen in numerous forms, such that all objects and creatures possess an existence before they appear. Actually, there is no existence to things that are seen (Sevgi, 2003, pp. 29-30). According to Sufism, a human's real mission in the universe is to reveal the secrets of the divine in the self by performing good deeds in line with what the Creator has determined, and thus reach spiritual perfection, attain the reality of oneness, and arrive at the Truth. The path for this passes before the spiritual discipline called Seyr ü Sülûk (Türer, 2001, p. 13).

In his work, Mantiq al-Tayr (The Conference of Birds), Attar depicts the neverending inner journey of a person, whose grasp on mysticism is connected to one thing, that is spiritually designed directly to God through a clear method (Cebecioğlu, 2005, 
p. 237) as a journey made to gain the enlightenment of the Hoopoe ${ }^{2}$ by the leaders of the birds on their quest to find the Simorgh $^{3}$ (Sevgi, 2003, pp. 29-30). Attar brings the degrees of mysticism, truth, and ingenuity that are accepted as the essence of Sufism through seven stages, consisting of quest, love, understanding, independence and detachment, unity, astonishment and bewilderment, and deprivation and death. In order to reach perpetuity, arrive at Truth, and vanish in its presence, these stages are stipulated to be under the guidance of a sheikh who shows the straight path (Argapuş, 2005 as cited in Aşkar, 2012, p. 9).

Many birds on this difficult journey fall to shame, are defeated by the bait of their appetites, and drop off tired, while only 30 birds overcome the valleys and arrive at Simorgh's pavilion. A harbinger of grace comes open the door to them and takes them inside. Pages are placed in front of them all, and they are told to read them. The birds see written on the pages what they had done up until now. From behind, the light of what is worshipped illuminates them and gives them life. It comes to clean and wipe from their memories what they had done before, as well as what they hadn't. The sun of closeness rises over them. In that moment they see the face of Simorgh in the rising of the light. But when they look at what they see, Simorgh has been formed from the 30 birds. They turn their heads and remain astonished. They can't comprehend at all what they have become (Attar, 2015a).

Ilahi-Nama (2015b), another work of Attar, is composed of 22 stories. This work describes the conversation of the caliph with his six sons. The caliph each time asks various questions to test the unique knowledge of his sons, wanting to learn their desires. The first of his sons wants the daughter of the first fairy sultan; the second, the secrets of magic; the third, the cup of Jamshid; the fourth, eternal life; the fifth, the ring of King Solomon; and the sixth, to learn alchemy. In the story's framework, each wish represents one of the ambitions that overcome people. In this way, the ruler specifies the meaninglessness of their desires and tells them to give up from the empty and insubstantial wants. Attar extracts moral and spiritual outcomes from the short stories that sprinkle among the main story of the book, and in the last section of the book he says "My poetry is from end to end the unfettered oneness of God before insufficient attributes; would it be a surprise to this if it were read in heaven? I have opened the door to a divine treasure; I give the name of God to this book." The stories are virtually flawless from a technical perspective (Sevgi, 2000, pp. 29-30).

2 An Afro-Eurasian species of bird known for its distinctive "crown" of feathers.

3 A Persian mythological bird, not unlike the pheonix. 


\section{The Stages of Human Desire and the Journey of Existence through Attar's Seven Valleys}

In his book, Mantiq al-Tayr, Attar explains through Hoopoe's entrance to the Valleys of Quest, Love, Understanding, Independence and Detachment, Unity, Astonishment and Bewilderment, and Deprivation and Death and process of enlightenment how to possess the title of completion (Altıntaş, 1986), being the Nafs-i Emmare ${ }^{4}$ that the disciple needs to overcome in the process of becoming a Sufi, how to reach one's essence, and how to obtain the knowledge that is within at the end of this life. Attar shows that if they do what is done to people through the way of stories, they will reach the spirit, the essence of a peaceful existence, and their own essence. When this and other works of his are looked at from a psychological framework in today's modern experiences, finding ideas that can guide people even with a worldview that recognizes any area of existence beyond the physical universe, as well as maintain its validity, becomes possible (Topaloğlu, 2003).

According to humanistic psychology, life is not just about meeting our basic needs. When left alone, people move ahead to the point of existence that is self-satisfying. Carl Rogers gave this point the name fully functioning person. Abraham Maslow, though, used the concept of self-realization. Individuals who have developed themselves pass beyond the path of being by being all that we can be. Rogers defined the process of self-discovery, which this person doesn't know how to finish, as the process of being (cited in Burger, 2006). In Attar's thoughts, speaking to us from hundreds of years before, by finding the signs of modern psychology and blending these signs in our lives at this moment, it is possible to show us the way in spiritual awareness and in the journey of existence. Acting as an intermediary to this guide, which is this study's objective, contributes to similar studies previously conducted (Aşkar, 2012; Günbal, 2014; Sevgi, 2003).

This article's main framework, even though structured in the form of stages of human cravings that occur mystically in the valleys crossed in Mantiq al-Tayr focuses on Attar's ideas about the qualities of human character, lifestyle, and the experience of self-realization, as well as what he has to say concerning spiritual development by blending mystical understanding with a psychological perspective while interpreting it.

This article was not limited to Mantiq al-Tayr, but also benefitted from the mystical visions that took place in the stories and comments of Ilahi-Nama, and Asrar-Nama (Attar, 2003).

4 Sufi term for the human craving that commands evil and takes pleasure in this. Nafs is the general term for human cravings. 


\section{Beginning the Existential Journey: The Valley of Quest}

Two of the most important questions in psychology are "What are people's motivations?" and "What gives direction to their behaviors?" Maslow, looking for answers to this question, identified five areas of need that people have. These psychological requirements are in the form of security needs, the need to belong, the need for love, the need for respect, and at the top, the need for self-realization. Even if these needs exhibit changes in exceptional cases, Burger (2006, p. 436) identified they show a hierarchical order and guide human behavior. Glasser (2008) identifies the needs of people as being loved/belonging, surviving/eliminating our physical needs, freedom/independence, the need for entertainment/gratification, and the need for power (self-confidence, feeling worthy, and achievement) and that the five basic needs are found in all people genetically, independent of culture.

While in opposition to this view, Frankl (1999) advocates that people whose physical requirements are unable to be provided can try to fulfill their quest for meaning, sometimes even jeopardizing themselves to meet their basic needs in the search for meaning in severe conditions.

In Sufism, a Sufi strives to constantly be a better and more beautiful person. One is patient in times of need, generous to a fault in times of plenty, and finds everyone in favor without discrimination. Even to badness, one responds with kindness. A Sufi tries to order the innermost world before external appearances, tame their human cravings and arrive at Truth, and earn the friendships one has (Öngören, 2009, pp. 471-472).

Attar emphasized people's views about their needs in the Valley of Quest. In this valley, a person's desires were in line with their needs. If one was in need of possessions, glory, or fame, they requested these attributes; if they were in need of spirituality, they requested reaching God. Consequently, whatever is needed is focused on and sought after.

Bread is always a need of the hungry person (Attar, 2015a, p. 133).

If one decides through the eyes of others regarding what is valuable and worthless from the things people want, it is not possible to see the bigger picture or arrive at knowledge. Sometimes really great knowledge is hidden among what seems worthless. If one learns to look properly and accept that everything experienced is valuable, then it becomes possible to understand the self.

If you appreciate pearls but settle for stones, you've no need to shop with the sultan (Attar, 2015a, p. 259).

This thought can be found in psychology in dependent and independent self- 
understanding. This concept contains cognitive representations formed by a person in order to develop how they are perceived by others; it is a state of being closely associated with the relationships constructed with these people. In other words, relationships with friends and loved ones create an important part of how a person sees one's self. One who realizes the self doesn't succumb to excessive concern on the topic of complying with community-determined behavioral measures, as long as they also don't remain insensitive to the needs of others (Burger, 2006, pp. 424-660). The Sufi searches for God's pleasure in works and wishes performed. A person who moves by what others think will be beaten to worldly attributes and be far removed from their essence.

Attar, while saying, "Son! Now you are searching for things that are already in you. However, you are being lazy and at a standstill" (Ilahi-Nama; Attar, 2015b, p. 84), denotes that people's access to information stems from the full power of self, but it must be through desire and effort. The fullness of knowledge is within. Disciplining human cravings, being patient, and reaching maturity are possible only by disciplining the self.

The one who doesn't have their eye set on seeing the Sultan has no chance of approaching the Sultan (Attar, 2015b, p. 87).

Human cravings found in the body are a matter evil to people and command mischief. War made for these reasons is war made over human cravings. The Nafs-i Emmare always orders evil. This nafs is the craving that guides people to the needs of the body, that fuels the taste for and sensation of lusts, and that orders people to perform these things (Altıntaş, 1986; Cebecioğlu, 2005; Coşan, 1994; Gölpınarl1, 1969). Nafs enjoys, worships, and admires the self; it is selfish, spoiled, and arrogant (Uludağ, 2006). For these reasons, Sufi thought is a systemization of all activities for disciplining, dismantling, and purifying these human cravings. Many biological and psychological applications have been made to bring these cravings under control (Altıntaş, 1986, p. 49).

Therefore, the most important quality for an individual to have to advance on the spiritual path in the Valley of Quest is patience and not lamenting what has been lost. Only if one is patient does one not deviate from the path. But if one is engrossed in temporary attributes that exist in the material world, such as money, fame, and power, then one becomes distanced from the essence. These attributes become the main purpose anymore, and one becomes a slave of the Nafs-i Emmare.

Whoever is attached to something from the path, that thing becomes their idol and remains attached (Attar, 2015a, p. 261). Suffer, be patient, sit like a man, and wait as well; may the time come when one day your work is in order! (p. 260) 
Attar specifies that suffering matures people and develops problem-solving skills, that being patient shrinks problems by dividing them into small pieces, though not instantaneously, and that coping is important. Furthermore, being able to experience happiness only through achieving awareness emphasizes that every bad event might have its good side, and coping with problems is sometimes necessary.

You cannot find a gram of gold without drawing a century of distress (Attar, 2003, p. 77). My dear, if you would awake from sleep, you would receive news of many joys... Is a rose in one place a thorn in another? Is a cure in one place trouble in another? If the remedy is not seen today, the edict reveals if death approaches (p. 122). My friend, there is a lot of sand on your path; remove each piece of sand. If you pull away the burden of sand one by one, it is easier than pulling down the pile (p. 218).

Frankl (1999, p. 26), the founder of logotherapy, identified that as long as people don't divest their desires to a great extent, there will be a point further downstream where they'll be able to be found. If deriving the highest point of human potential is desired, on must first believe that this exists. Otherwise, he says, people will degenerate because there is a potential directed to the worst.

The purpose of Sufism is first, for one to gain knowledge about the self; then, raise them to the state they need to be in. The reason for being has an important place such as this in the universe of human existence; according to this approach, humans have a divine substance that appears in the mind, namely, the Nafs-i Natika (Altıntaş, 1986; Türer, 2001). Gradually increasing, maturation passes in a moral sense until human cravings, which are directed at the internal world of self, reach the Qur'an's appeal to “enter paradise" (Altıntaş, 1986, p. 51).

According to Attar, in order to perform this initial maturation and not get stuck in the Valley of Quest, one needs to possess qualities that will advance toward the path of mysticism and the stages of human cravings. In these qualities, being measured in desires, many were those interested in how they appeared in the eyes of others; for this reason one focuses on not being overcome by glory, fame, and wealth; being patient; making efforts and sacrifices in order to reach one's aspirations; acceding for those who cannot find solutions; not wanting from others what cannot be given oneself; and being focused on the existential self while thinking that the source of knowledge is the self.

\section{Awareness and the Nobility of Repentance: The Valley of Love}

The situation comes as a discontinuous, temporary feeling in Sufism. There is a selfspecific condition for each station that has been reached. The conditions of the Sufi who has risen from one stage to another also change, and these conditions endure changes 
toward higher perfection until infinity (Demirci, 1997, p. 216). If one has passed from the Valley of Quest, the Valley of Love is reached next. It is the person in the Valley of Love who has been interrupted in love with fire, who goes and runs fervently, who burns, who is burnt, who doesn't think of the end of work even for an instant, and who is in circumstances that care about nothing. On the road of the lover, one is good as well as bad. Besides, as for love, it neither stays nor is such. Attar explains this metaphorically, saying, "Is the fish removed from water also laid flat? It stops struggling, saying 'Maybe I'll be released to the sea again"' (Attar, 2015a, p. 263).

Attar relates feelings and intelligence with each other. Reason and emotion are like smoke and fire. Fire creates smoke, but conversely, when fire increases, the smoke decreases. The mind and emotions are together, but if feelings are too high, the mind starts to lose its impact and cannot understand emotion deeply (Attar, 2015a, p. 263). Greenberg $(2012$, p. 3) asserts that first we feel, later we think, and often times, we also think as we feel. Greenberg states emotional changes in this way become the key to permanent cognitive and behavioral changes. In modern psychology, what this interpretation brings about overlaps with the idea of Attar's thoughts about feelings.

When Attar says the mind goes concerning emotion, the meaning here is due to the intensity of emotion in a non-maturing mind. However, this is not going crazy through intense emotions. The humane approach in psychology asserts that on the topic of people discovering their true feelings in counseling, as much as they can behave freely, they will also be able to come closer to arriving at their true self (Burger, 2006, p. 464). According to Attar, the effort that helps one not get lost on the path of love in this valley is being dignified with diligence.

The throw rug of the ant is very dark, but it is from the arch of attempt being girded. Don't look contemptible, even to the ant. In it, in its heart, is a lion in repose (Attar, 2015b, p. 56). First one should look then set foot on the road, because one doesn't journey before seeing the road (p. 57).

Attar indicates that people who fail to notice the good for themselves focus on choosing information that only supports their experience and reject information that corresponds with solving their problem. Therefore, they can't develop and are always stuck in the same situation. This situation can be compared to diagrams in psychology. Diagrams resemble people's road maps that they follow to show themselves the way concerning their lives and relationships (Dattilio, 2015; Türkçapar, 2015). Whether consciously or unconsciously, beliefs received from one's parents and immediate family are found to contribute to common views that cause the existing family development to repeat throughout one's lifetime, starting from childhood (Nichols, 2013; Young \& Klosko, 2015). Schemes are assumed to be relatively more stable, they reach a state that from time to time doesn't yield. Usually, diagrams can vary 
in those who are strong as much as new information they perceive can change their beliefs. When new information comes that is incompatible with the resistant schemes and threatens their fixed idea, instead of accepting this new idea, the fixed ideas can become more stuck (Dattilio, 2015).

In a story from Asrar Nama, Attar explains this as:

A dustman left for work one day

He would sweep in front of Attar's store that day.

From the shops spread the scents of musk

The dustman's head turned and straightaway he collapsed.

It was as if his nose were unaccustomed to the pleasant scent and in that moment his life had left his body.

Attar left his shop to go outside

He brought agar-wood oil ${ }^{5}$ with lots of rose water.

The stupor on the dustman's face, wet with rose water and agar oil, was worth noting at that moment.

Another dustman saw his state

He brought a piece of feces close to his nose.

As his nose took in the smell of the stool

His two eyes opened and in that moment he came to (Attar, 2003, p. 83).

Attar has stories where schemas have a negative impact on problem-solving skills. A problem is constantly bigger in one's own eyes; if they avoid solutions and expect others to solve their problem, his stories say bigger problems become intolerable, and therefore one's human cravings cannot be disciplined. He explains this view in a short story from Asrar-Nama:

A mosquito complained about the wind

It left Solomon's presence while whining:

Save half of my life with your justice

If not I will make life unbearable!

Solomon sat the mosquito at his side

Then he called the wind to his side.

As the wind hastily came from afar

The mosquito started to fly away.

5 One of the world's most expensive incense oils. 
Solomon said, "No wind shall persecute you"

But the mosquito couldn't take it

Were the wind to blow, it would escape

How could the mosquito handle the storm? (2003, p. 79)

According to Islam, there is a mutual love between God and His servants. God loves His servants as they love Him. Qualities that provide servants with God's love, such as repentance, cleanliness, patience, piety, kindness, justice, and reliance, are elaborately developed by the Sufi (Öngören, 2011). Within these, the individual must pass to the stage of Nafs-i Levvame, or human cravings of condemnation. In this nafs, one is aware of the bad things they have done. Therefore, they condemn themselves, don't want to do these bad things, and repent; they don't just continue doing within what hasn't sufficiently matured (Cebecioğlu, 2005, p. 199). Attar signified that humans need to continuously examine and critique the self this way. Thus one can notice and correct the mistakes they make.

That you should see a grain of your own shame is better than seeing the Unseen or the hundreds of lights that hold the Unseen (Attar, 2015b, p. 340).

Everyone is in love in the Valley of Love. For some, it is love of God; for others, it is corporeal love. If a person is oriented materially, such as love of glory, fame, power, or sexuality, they cannot pass beyond this valley; by not arriving at their essence, they remain mired in the Valley of Love and unable to discover the self, as if this valley were the only truth. If one is aflame with love of God, they repent to receive His consent and try to always notice their own flaws.

Sacrifice is important in the Valley of Love. A person doesn't think only of oneself. Loving someone, they make sacrifices for them. If this is love of God, they need to give up all worldly attributes, even from the self. One with raised awareness; who hasn't alienated the self; and who is diligent about being cautious, devoted, grateful, open to knowledge, and solving one's problems can then continue to develop by passing through to the next valley.

\section{The Journey under Guidance of Knowledge: The Valley of Understanding}

The Valley of Understanding is the third valley in Mantiq al-Tayr. One who has passed through the Valley of Love is now in the Valley of Understanding. On account of people's abilities being different, what occurs in this valley is in accordance with one's skills.

Everyone's walk is slender perfection; everyone's familiarity is light-headedly circumstantial. 
Were you to fly as the mosquito wanted, could you ever secure the speed and strength of the hurricane? (Attar, 2015a, p. 273)

Therefore, each and every person's level of progress and path followed are different.

So many ways are seen summated in that valley, but every single way is in consideration of the traveler! Each and every person will have a different goal that they arrive at in the end, because each one has progressed under their own power. Here, knowledge is therefore distinct. Some knew and found the mihrab; others, the idol! (Attar, 2015a, p. 273).

In the Valley of Understanding, it is important to know what real knowledge is through one's own qualifications. Whether an individual is aware or not, there are also some realities. One must compare their own qualifications with these realities. Otherwise, one will probably feel frustrated and fail.

All good things do not beg from God. The human cannot ask for other than what one is worthy of; one cannot ask for something sublime from the powerful. If there is something you wish of merit, it already comes forward at once; it comes spontaneously (Attar, 2015b, p. 128).

Humanistic personality theorists explain depression through self-esteem. Often, those who enter depression are people who are not aware of their own self-worth. While treating people suffering from depression, getting people to accept their own mistakes and weaknesses is an important aim for humanistic therapy (Burger, 2006, p. 31). The common point of knowledge given by humanistic therapists with Attar's views is the emphasis on a person's contribution that they develop to reach the awareness of their strengths.

Attar explains his idea related to awareness with the story of the Felled Tree in Ilahi-Nama:

One man cut down a green tree. A troubled person passing through there saw the branch say: These lush green branches from the tree they cut no longer have anything to do with trees. There is no news now, even of what has been cut. Because of that, it is in a fresh, green demeanor on top of the road at rest. For now, it knows not the suffering that incurred, but a week later it will understand. You have no news of your current state... (2015b, p. 135)

If one but notices the self, one notices others. However, others can then understand what you feel. How can it also be that a person unaware of their own heart can find the heart of another? (Attar, 2015b, p. 133)

Sometimes we are also unaware of our own feelings and behaviors; however, these things see and are aware of others. One, especially one who can't control feelings like anger, turns to feelings and behaviors that others notice but that they themselves don't control or nourish. 
You don't see the envy and resentment in you, but the eyes of capable men see. There is a furnace filled with dragons in you; you have unleashed them in you heedlessly... (Attar, 2015a, p. 230)

Because of many negative behaviors that have emerged, in case one experiences a problem in developing skills for coping with anger healthily, people are directed to mental health centers. The need to control one's anger is what is most intensely emphasized in all that have been referred. These referrals generally don't come from the self; they come from one's environment (Cummins, 2006). One's anger is mostly directed at people they know well. They are often spouses, children, friends, and people they work with. Anger that shows up in the face of frustrations that are experienced cause one to undergo further frustrations by transforming this feeling into regret. In this case, people's relationships in their environment are disrupted, their interests crumble, and their concentration regarding the work they do is impaired. Anger, while preventing the mind from functioning healthily, also triggers aggression (Greenglass, 2005; Köroğlu, 2011). Anger both disrupts social relations and is also the reason that a disciple in the process of enlightenment succumbs to their human cravings.

Attar highlights the need to not be arrogant while using one's knowledge and to also not be closed to the idea that without it, nothing would exist.

Should every moment perish once, there is nothing wasted to God. It is useless that you should spend a lifetime in forbearance, or even longer in patience. The Truth is that you are not. Discretion commends dividers like this. There is no one who knows even the tip of it. What news of the heart there is from the heart is that of life. Only without this, in stopping the pace of work, is it also without life (Attar, 2015b, p. 132). A doofus departed from the door with candle in hand. He saw the sun shining so bright in the sky. The mind of one who thinks from ignorance cannot possibly see the progression of the sun, let alone this candle (2003, p. 134).

The human believes it is from the self that good is done, and from others or from surrounding conditions that bad is done. This is not correct. According to this, whether a human does good or bad, it is an act of their own choice.

The bowman wished from the bow, should the arrow fly straight and the target be struck, this is a blessing. But should the arrow go astray, he immediately rains down curses to the arrow, speaking bad words. I know not anything more surprising than this (Attar, 2015b, p. 134).

If a person is aware of their knowledge and skills, than they know from which path they need to proceed. Thus, one discovers their values and essence inside. Who a person is shown by these values. A person, if they don't just strengthen their values of bad or good inside, can pass on to the next valley. Aside from this, one needs to notice today without being stuck in the past or the future. One squanders their life sighing for the past and living in fear of the future. Instead, one should look at what is wrong today. 
Do not attract the grief of yesterday or of tomorrow. A human does not get caught up in love through futile affairs. Do not carry the sorrow of things that haven't come. One is not helpless against what has passed. Do not eat the sorrow of poverty and sustenance. Day and night, there is no other sorrow than the sorrow in it. Sorrow is but one of two worlds. If today you have sorrow about tomorrow, it means you have wasted and disposed of the life that is in your hands today. Do not worry, for there is no partner of grief in the world. Should you give in to grief, there are thousands more in every moment, but it is maturity to be pleased in distress. If one seeks pleasantness of the heart, it is an impossible task. What do you hope from joy that will bear sorrow? What is it that you wish from existence born of nothingness? Joy comes to you from God. If it isn't coming, you have no luck; dive into the sorrow of this, it is the affliction of nothing else... (Attar, 2015b, p. 138)

Despite all efforts, accepting that what is not comes from God makes it easier to withstand the pain. It is not possible for a person to achieve everything they want. Neither skill nor strength is enough for this sometimes.

Learn bravery from the damned Devil. ${ }^{6}$ He came as a soldier to the square of bravery and accepted everything that came from God (Attar, 2015b, p. 150).

Sometimes the skills and knowledge one has does not provide the opportunity to achieve everything you want. Therefore, accepting the situation as is facilitates withstanding pain and failure.

Whereby the world is not stopping, it is passing through and going; you too pass through. Leave it. Don't look at it so much. A soldier who is devoted to something that is not eternal is not the saint with a heart (Attar, 2015a, p. 188).

Sometimes failure or the inability to get what one wants can unexpectedly bring a person back as a successful person. Therefore, a situation that initially creates sorrow can later be the key to happiness. Realizing these benefits both increases control of sorrow and also minimizes the unhappiness coming from being unsuccessful.

If what Satan cursed had not been nourished, from where could he have shown this power against the people? While pleased with the curse, he wished mercy from God, his curse also being accepted wholeheartedly, wishing for eternal life... The curse of God was death for others, but to him it was an object of divine manifestation (Attar, 2015b, p. 151).

The goals deemed necessary for overcoming Attar's Valley of Understanding share similar characteristics with the goals that target development in the deliberations of existential humanistic psychology. The aim of existential humanistic psychology is to assist those who know how to experience the moment alone or with others who have consulted, to enable them to stay living in the moment and notice how they were or weren't successful, to take responsibility for their lives, and to help select

6 The Devil, or Satan, is known in Islam as Iblis, and was not an angel, but a genie raised to be with angels who rejected God's command to bow to man. This is how Iblis came to be cast from heaven and the enemy of humanity. 
and implement existing ways of consultants based on confronting these realities as opposed to fleeing from them, such as finiteness, ambiguity, and anxiety (Schneider \& Krug, 2015, p. 46). A different perspective of Attar's identifies a person on this existential journey who arrives at Truth beyond a finite life and reaches survival by disappearing into one's existence.

The disciple who can overcome this stage possesses human cravings at the level of Nafs-i Mulhime. This human craving has the will to separate good from bad, and inspires kindness in the owner. This is the third stage human cravings have reached. It is a degree of improvement. Anymore, human cravings are identified with God's help as a good deed or a sin; for this reason, they move away from anything that is away from God. These cravings that turn souls to the universe are in a state of love; enjoy knowledge; and are generous, frugal, and humble. Patience and strength of endurance increase. It is tolerant and flexible to toil and persecution. It remains as an admirer of the cosmos, abandons people, and approaches the Truth. Their words are beautiful and wise (Altıntaş, 1986; Cebecioğlu, 2005, p. 200; Gölpınarlı, 1969). To advance in disciplining human cravings in this valley, one needs to have no doubt concerning their faith, and accept that it is God who inspires both goodness and evil (Coşan, 1994).

Satan said "Curses, your sultan reads. But prior he looks at the goal. Before the arrow is loosed from the bow, the target is noted. Now you are aware of that arrow. But if you have eyes, prior, take a look, you! (Attar, 2015b, p. 155)

People are focused on how they will reach their goal while developing their goals. Just focusing on this is not enough. A careful review and awareness of people's values, essence, and needs that make up goals is what actually need to be done. A process only focused on an outbound destination, even if it is satisfying, may not really be one's goal; as a result, one would not feel satisfied and would be unhappy. Sometimes, also, one can observe improper methods at the cost of not achieving the goal. In this case, it causes unethical behaviors and harm to others.

In order to be able to pass through this valley, a person must have understanding; in other words, they must have knowledge and achieve their goals. One must also be aware of self-essence while forming goals. The road traveled will be different for everyone, for everyone's knowledge is different. Therefore, it is necessary to know the limits of and develop one's skills and knowledge. If one only develops goals for the material world and exhibits their ingenuity this way, they will brag excessively about their knowledge, be closed to the idea of everything disappearing without them, and with God's permission they will forget the knowledge they have learned; if they are a prisoner of knowledge, they will not move on to the next valley. 


\title{
The Gate of Existential Essence: The Valley of Independence and Detachment
}

Attar's fourth valley is the Valley of Independence and Detachment. ${ }^{7}$ Everything learned in the Valley of Understanding completely changes in this new valley.

\begin{abstract}
If the stars are spilled piece by piece from the heavens, imagine a leaf gone missing from a tree in the universe... If two worlds completely disappeared, imagine a grain of sand disappearing from the world... If nothing remained of the works of jinn and man, imagine that a drop of rain went missing... two worlds again, if you gathered up hundreds of thousands more, shuffled all that there is, and mixed it, only a mirage would appear to you; it consists of nothing that remains on top of a riddle! (Attar, 2015a, pp. 280-281)
\end{abstract}

That which God wants is fundamental in this valley. The rest of everything is nothing. It is whatever God wants. If He wanted, ant could have the strength of 100 elephants for no reason. Say the mind of a raven achieved spiritual perfection; even one person from within hundreds of caravans would not be left alive.

Hundreds of thousands of people girded with zunnars, ${ }^{8}$ finally, one Jesus was the ointment for secrets (Attar, 2015a, p. 280).

In this valley the most important characteristics are acceptance and thankfulness. According to acceptance and commitment therapy, actual acceptance is not a thought process. It is being open to bonding with the self that can see, an attitude of showing interest and comprehension. In the process of acceptance, the self that thinks is put aside and transitioned to connect with emotions experienced through the self that sees. It is observing feelings that experience the aim in the process of acceptance; it is not thinking about this (Köroğlu, 2011, pp. 146-147).

According to the understanding of this theory, whatever a person does, they should lose their whole self in their work. Whoever they are together with, they should really be in their work. One should be able to be in thoughts that don't interrupt work, or if it remains stuck in them, be able to distance themselves from these thoughts. If one encounters feelings that aren't enjoyable, one should make room for them. One should know what needs to be done for every problem by being aware of what one experiences in the moment they experience it. If it cannot be solved, it should be accepted as it is (Köroğlu, 2011, p. 152). Attar similarly emphasizes that the processes that exist in this valley would assist the disciple's development in accepting the process of Seyr ü Sülük as the divine will of God. The disciple is both passive and active in this acceptance. Passive in the will of the Truth, but counter to this will, active in self-development and in comprehending it.

7 Feeling sufficient through God; without need.

8 Zunnar: belts worn by Christians and Jews in the Middle East as part of the Treaty of Omar II, to denote their religion was not Islam 
Greed and ambition are the qualities that inhibit passing from this valley. It is not possible for an individual who has these qualities to progress in disciplining their human cravings. Greedy people cannot know or give thanks for the spiritual power that is in their hands. They always want more. In this case, they begin to lose what is in their hands and cannot understand its value.

You do not know that you are lost in imitating silver but heedlessly counting off your valuable life to nothing as if it were gold... (Attar, 2015b, p. 352).

Sometimes the result of our goals, wants, and behaviors may not be like we want, even if they seem very good; we can even see the harm from them. Therefore, we need to weigh well what we want and how we behave. Attar brings this idea to words through this story:

A fly saw a honey pot sitting in a nook while remaining wandering for something to eat... "Where is the man that" it said, "if you had the foresight, you'd assure I wouldn't lose my dewlap! Does he give a fruit unlike the plunge into reunited love again? What is there that is better than honey?" Someone has brought to bear the desire of the fly. Opening the mouth of the jar, he took a barleycorn, which helped the fly enter the jar. The fly, dropping to the honey hand and foot, became thoroughly stuck. It made to escape by wishing. It sunk trying to jump out. It cried out, "This honey damns me; this is worse than poison for me"... (Attar, 2015a, p. 284).

One has reached the human cravings of Nafs-i Mutmainne, that of fullness, peace, and return to comfort. These cravings have been stripped of bad attributes and are moralized with beautiful ethics. This is the fourth stage of human cravings. In this stage, the sorrows of the nafs have ended, and the heart has become, above all, sure. The heart of one who has these cravings that go straight to God possesses complete and true belief. Having achieved some of the secrets of the Shari'ah, one has gained attributes like generosity, correctness, soft heartedness, geniality, and sweet speech. One is ever more in a state of trust, accommodation, surrender, patience, and consent. One's heart, every moment in peace and tranquility, gives thanks, covers flaws, forgives mistakes, and doesn't separate in the least from the commands of Islam. With God's permission, they have come to possess several discoveries and inspirations (Altıntaş, 1986, p. 47; Cebecioğlu, 2005, p. 199).

Anymore, progressing on the spiritual path, they have passed to an existential phase. In this valley they accept the knowledge they have obtained and attempt to search for real meaning. Sometimes this spiritual power can be different from what has been seen. That is the reason being grateful and accepting are the two most important qualities of this valley. Something what appears good can be evil, and something that appears evil can be good. In this valley, there is no chance to enter another valley for those who are overconfident, who have become slaves to knowledge, or who cannot understand the meaning behind what is seen. 


\section{Essentials Are One, Everything Else Is Nothing: The Valley of Unity}

The fifth valley is the Valley of Unity. All people who have reached the Valley of Unity from the Valley of Quest realize that they are one in this valley. There is no longer a difference from one another. The number, whether it be many or few, unite together on this road; all are one.

Every number consists of one time, many repetitions of one (Attar, 2015a, p. 286).

This state of being one is a condition of body and soul being one. Anymore, whatever direction one turns, everyone turns the same. It integrates the personality. The human arrives at the essence of being. This essence is the same in everyone and also carries the light of God; good and evil are from God. Attar explains this as resembling a mirror erased of secrets.

If your mind and your body become enlightened, your body immediately becomes life, and your life instantaneously becomes your body. The darkness of the body resembles the back of the mirror and what you call life is radiance, like the face of the mirror. When they wipe the back of the mirror, beautifully the two sides become one; what dirt, what a thing remains... If the back of the mirror is like the face, when you turn towards the face, one also becomes visible (Attar, 2015b, p. 59)

Attar likened attributes such as glory, fame, and wealth to a palm sapling decorated with a hundred various shapes. The tree that is made from the palm-sapling beeswax is an ornament with several portrayals. Even with hundreds of forms in the sapling, should one handle it from top to bottom; it becomes lost and withers. Seeing as each and every ornament will gave up from them, one has to not identify existence or its essence with temporary situations. If a person, being me, connects to a temporary situation like wealth, glory, or fame, experiencing deep disappointment is likely. This is because not having the happiness that comes from the essence, one gets stuck in the back of the temporary situation and cannot arrive at the core.

You, there is quite good and quite bad in existence. However you were lost, did you leave space; all in all things are empty. You, should you stay in your own existence, you will see good and bad; the road goes far! (Attar, 2015a, p. 288).

Adler (2003) identified that a person, if one shows effort in order to have others accept the self, whether or not the highest point has been reached, this person experiences a tension in their spiritual life. This person unrealistically expects a big victory by struggling to constantly be on top. People like this have lost their sense of reality, because they always stop to think about what others think of them and how they leave an impact on others; they lose their connection with life. According to them, an individual's existence progresses to the better through providing more harmonious relations between the individual and the environment, and this progress 
has no end (Adler, 2002). The Sufi's journey of Seyr ü Sülük is also the struggle of perfectionism, but this perfectionism occurs through the spiritual relationship established with God and lasts forever (Öngören, 2011).

In this valley, everyone becomes equal in order to discover their essence. This is the essence God has bestowed on them. Everyone has been freed from temporary happiness and from power. If anyone has taken power from others or behaved arrogantly, here they are the real loser. This is because all of these forces actually don't belong to them. It all exists with the support of the environment. Therefore, the fear of losing support is a very intense experience. They constantly feel the need to take precautions. If they lose these, they think they'll lose their existence. Attar shared these thoughts in his Ilahi-Nama through a metaphorical narrative in the story "The Namesake of Sultan Mahmud."

When Sultan Mahmud went with an army that filled the desert plains and that rested against the tip of destiny,... He saw an old man, afflicted, bent at the waist, barefoot, completely bald, and face dust-ridden... The old man came over to the Sultan and said "O mighty soldier." "Come tell, what's your name?" "My name is Mahmud" the old man said, "I'm your namesake, already this is enough for me"... "You are a Mahmud, I am a Mahmud. But how can the two of us be the same?" "My sultan," the old man answered, "it disappears in us; if we go two arm-lengths below the face of the earth, our state of being Mahmud becomes equal and equivalent. For now, I am contemptible, a small man, but when we die, I become the same as you"... "without the opportunity for you to rest, even for a moment, pray tell what in the world do you rule over? If you can go to such a loneliest of lonely places, without such an army, your work becomes ordered... It is impossible to even sleep at night without protection." (Attar, 2015b, p. 289)

Rogers (1959), by his focus on internal evaluations, saw freedom of movement as a sign of self-management and mental health. When the focus of evaluation is external, people rely on the views of others, authority figures especially, and other authoritative sources in order to conduct their lives. On the other hand, making decisions based on personal beliefs, values, and feelings can be riskier but provides a sense of pride, faith, and self-confidence (as cited in Cain, 2014, p. 40). According to Attar, one who turns to the core of self and receives inspiration from this core receives inspiration from the Truth, because this core carries a piece of God. If a person relies on strength, power, and temporary forces, that is all they will ever find, because all of these are temporary.

If your essence becomes interested with God, it becomes interested in your essence in God. However, if your essence deals with the material body, it moves away from the source of the essence, and now the roads that lead to God appear hilly, long, and arduous (Smith, 1932). 
If you are part of a whole, melt inside, and go on the spiritual path, you pull out the existence that is the essence. This separates you from everyone, but at the same time makes you one with everyone.

If you were to be painted the color of the sea today, you'd become a pearl shining in the sea of night, illuminating the darkness. But by imploring your existence, what life, what wisdom, you can find (Attar, 2015b, p. 218).

In order to achieve these, one must remain alone to deal with one's own essence and turn to spirituality by withdrawing from the world. Attar depicts this as the transition from childhood to adolescence. But in order to make this transition, one must pass through nothingness and be cleansed. Then one can begin the journey of finding one's existence and reach the core of self. Whatever is in that essence, it has been found.

Pristine Jesus was placed in a village. The Jews, without fearing God, set out to curse him. As they cursed that lineage, the cleanly prophet prayed for them beautifully. Someone said, "Why aren't you angry at those cursing you, why are you praying for them?" Christ said that the owner of every heart with life spends whatever there is. In the sea of life, whatever the wave breaks away is from it, the wave brings it to shore (Attar, 2015b, p. 275).

The feeling of solitude occurs in the moment we realize that we won't depend on anyone for approval. We learn to listen to ourselves in moments of solitude. Before being together with others, we really should enjoy being able to stay with our selves (Corey, 2008, p. 159). People with self-realization prefer to spend most of the time on their own, even if they have close friends of their own (Burger, 2006). Yalom (2000, pp. 559-560) identified that individuals are often isolated from others and parts of their self, and that no relationship they had established to avoid this is able to prevent it. This emphasizes that it is because everyone is existentially alone. According to Attar, the human is not alone because within their existence is the essence of Truth. Being alone in humans is for reaching this existential core, and in order to be able to reach this core, remaining alone is consciously preferred.

In this valley, a person is at the stage of Nafs-i Raziye. These nafs are the cravings that come from God, that consent to everything, and that remain satisfied (Gölpınarl, 1969). One has arrived at the stage of acquiescence. Human cravings that are in this condition give up the will of self and are subject to the will of Truth. One never complains about anything. Nafs have been beaten, freed from human characteristics, and arrived at evil. Now it is completely adapted to the commands and prohibitions. Beautiful morality arises in the self. At times, it is the recipient of the manifestation of God's names and attributes. One's personality is goodness (Altıntaş, 1986, p. 47; Cebeci, 2005, p. 200). Yet if a person has been cleansed by all attributes, the light of God begins to shine on them. If profanity or curses come, they are patient and accept that all is for reaching God. Everything is for earning God's pleasure. 
After this, Satan said, "O the immaculate light already appeared so bright to me, from what curse is there that I fear? Damnation is yours, mercy too; the slave is yours, and kismet, too! Whatever befalls my fate, what sorrow... Heaven being every theriac ${ }^{9}$ it is not; I need poison!" (Attar, 2015a, p. 258)

In the story quoted above, Satan, who had witnessed the light God breathed into man while creating him, had arrived at the secret. He had suffered the curse, for arriving at this secret was not within God's pleasure; but because Satan for now possessed this secret, he pointed out that no pain or curse would hurt him and that it is pleasing to everything that comes from God. Attar emphasized that by way of Satan, everything in our lives will not be able to go as we want, but that even these experiences that we don't want, once we realize what we have, will make sense.

One has arrived at the core of existence in this valley by detaching from all attributes and knowledge. This essence includes information about being human. One must be alone in this and be interested in the existential purpose of self. If a person continues to turn towards spirituality, the core they will arrive at is the light that God has breathed in them. However, if they could not pass beyond the material body, it is evil they will find, and the spiritual path will begin to appear difficult to them anymore. Thus they will remain stuck here and unable to pass to the other valley.

\section{The Valley of Astonishment and Bewilderment Where All Roads Are Lost}

The sixth valley is the Valley of Astonishment and Bewilderment. In this valley, one is a fire that has been cut frozen, or ice that has been flashed and burnt with trouble. One is in amazement. In the stage of unity, everything they had acquired was lost. Even their disappearance is lost. One was in trouble and yearning. Attar brings this to his writing as follows:

I'm in love, but with Whom? I don't know Him. He is neither a believer, nor an unbeliever. So, if it's like this, what am I? I already have no news from love. There is both my heart filled with love, and also nothing that tweets within my heart, so empty! (Attar, 2015a, p. 294)

In here, knowledge changes, and actually becomes useless. One has lost the path they were on because they remain bewildered. Those who know truly have lost their accuracy, those who knew wrong have lost their inaccuracies.

I don't know anything. I wish I knew! If I knew one thing, would I remain so surprised?" (Attar, 2015a, p. 300)

9 an ointment or other medicinal compound used as an antidote to snake venom or other poison. 
Those who grasp that everything in their life comes from God and who admire its beauties remain. Everything is His work. Anymore, they are awake. They are in submission to the whole of existence. Feeling this surrender and the light of God that is in their core makes them the possessor of trouble, because everything they knew has been lost and all spiritual power has changed; they remain bewildered. Any longer, the form of life, cognitive process, and all attributes that they had do not show them the way, because each one has become meaningless.

If you have a problem, you're already awake; day and night you set out to worship and you are not idle. If you need someone to wake you up, it means there is occasion for another man who will worship in your place... Whoever has been kneaded by troubles of the heart, they have been saved from hell, from heaven, too. The two of them do not exist in your eyes (Attar, 2015a, p. 251)

One has arrived at Nafs-i Meziyye, the sixth stage of the nafs. One moment, all life is delivered on account of the grace that comes from love. One is ready for God's command through all existence. The cravings have been satisfied and have been pleased by the self. God is pleased with these cravings. Nafs have gained this attribute: abandoned of human desires and with good manners. One has beautiful virtues that forgive defects, that are considered lovely, that are compassionate and bounteous, that love people for the sake of God, that are sensitive and tactful, that account for the nafs in the best way, and that are not had by everyone. These nafs are privy to some unseen secrets from God as permitted by God through fate (Cebecioğlu, 2005, p. 199).

The man said, "Even if your goods and property were filled with hundreds of worlds, they'd all say love to your selling a cup of wine!" (Attar, 2015a, p. 264) The old one plants a few sapling fruit trees. The sultan said, "Your hair and beard are hoary like milk. Still, there are few days in your life. Why are you planting trees here?" The old man had more words for the sultan. "For us, many people plant seedlings. That's why we have eaten and collected fruit up to today. We need to plant for others, too." (Attar, 2015b, p. 58)

These feelings recall the summit experience as portrayed by Maslow. Experiencing the summit is a moment that exceeds one's perceptions of time and space, forgetting all human concerns, integrating with the universe, and experiencing the sense of power and wonder. According to Maslow, people who live this experience become more heart-felt and appreciative of life, not allowing the problems of life to be a bother (Burger, 2006, p. 439).

In this valley, the concepts of important and unimportant have changed for people. A situation that appeared so important to one individual can now seem meaningless to them. What appeared so absurd to others is like an indication of God's supreme wisdom to him. Even an ant in nature looks different in his eyes by containing the wisdom of God, and he feels respect. One does not see one's self superior to anything. One notices an existential purpose in everything. Anymore they are in amazement 
because they understand and remain amazed that even the smallest thing has meaning. In this way, they take the road straight to the last valley on their spiritual journey.

\section{The Valley of Deprivation and Death Where All That Has Been Lost Is Found Again}

The seventh and last valley is the Valley of Deprivation and Death. This is the valley of forgetting all and rediscovering yourself. Deafness, muteness, admiration, all comes into existence here. People feel peace and leisure in this valley. Now having found the self, one is integrated. One knows one's self, what they've done, and realize their features.

If thrown in the wood fire with the agar tree; the two of them burn, becoming ash. The two of them in counterpart are ash; the two of them become one and the same. Nevertheless there is a considerable difference between them in terms of attributes! If one of them, filthy and unclean, disappear into the ashen sea, it will be left aghast in their own attributes in a state of inferiority. But a clean soldier, should he dive into this clean sea and not survive his existence, his motion will be interrupted by the movement of the sea. He is both not there and there... (Attar, 2015a, p. 302)

A person who has increased their awareness leaves being a part of the system and comes to an individual state through his existence. This motion of existence is a strange one. What determines whether one arrives at Nafs-i Kamile with a pure nafs or a bad one (Stone, 2006)?

I was a drop; I had attained the secret of the sea and disappeared. Now there's no chance of finding that drop! (Attar, 2015a, p. 312)

While describing mental health and its illnesses, Perls, Hefferline, and Goodman (2000, p. 21) related this to people identifying with or alienating from their core. If the person ever identified with their formative self, creative features were revealed and resolving existing problems was achieved. They could reveal their power against the world's difficult conditions and make the best of what's at hand. In contrast, those who weren't themselves organically and distorted their figure or background from this perspective impaired their mental health if they adhered to what wasn't a part of them.

Similarly, Attar highlights that the essence of the thing, as well as the existential journey, found in the end by one who seeks the self is an individual experience.

One night, moths gathered in a narrow place and were put to searching for a candle. All of them said, "Someone needs to search for what we want. Bring us news, even a little bit!" One moth got up and flew. He saw a mansion from afar; inside was a light like a candle. He returned and opened his notebook, then tried to explain as much as he understood. In that community there was a famous moth who condemningly said, "There's no news from this one about the candle yet." Another moth embarked to that candle, he blew out the candle 
himself, and like one unmarried, returned. It reached its wish by flapping its wings... The candle came above, he was underneath; he had turned back and told a number of secrets, mentioning the reunion of the candle. While the famous moth again said, "My dear, this is not the brand of a candle, you are like the other one; from where will you give your sign?" Another moth, completely drunk, embarked to the fire by tapping their feet. He had given up on life; he dove into the fire and beautifully destroyed himself. The flame wrapped the moth from head to toe. All of his limbs were severed by fire, he was fiery red. The moth condemned the others... He said "Here only that moth engaged his work. Who knows what? From the candle, only he has news" (Attar, 2015a, p. 304)

In the quest of self-realization and arriving at one's core, which was represented metaphorically by passing though each valley, while possessing some qualities enabled this journey to be completed, the qualities of a person that had been installed beforehand and expelled from their own essence were understood to not belong to the core and to alienate one from the self.

Fromm (1995, p. 30) designated resistive force as fearlessness and made three types of characterizations for it. The first one is where a person can be fearless because they don't care to be alive; but despite not fearing death, they can be afraid of life. The second type of fearlessness is that of a person bent at the neck, as though an institution or idea, an object of worship, is sharing their life. The third kind of fearlessness is closer in definition to that of the person in Attar's Valley of Deprivation and Death. It is seen in the strictest sense in the developed human who remains with their own self, who trust themselves, and who love life. A person who has defeated the satiated ignorance doesn't cling to any object of worship or any one thing; consequently, they have nothing to lose. They are wealthy because they are empty; they are strong because they are not a prisoner of their desires. They have advanced toward the goal they want to achieve; however, if they have yet to arrive, their fearlessness will not be complete. Yet, everyone who tries to take a step towards being one's self with complete understanding feels a new phase of life has begun when taking a step in the direction of fearlessness.

Humanistic psychology defines as individuals those who accept, such as being healthy individuals from a psychological perspective through their own strengths and weaknesses. According to them, by feeling anxiety because of the bad things they've done or by feeling guilty themselves, these people don't stay stuck on the past in order that they accept themselves as they are. No one is perfect. Individuals who have developed themselves, even if they go against society's expectations, act freely, regarding their wants (Burger, 2006, pp. 437-438).

The disciple that is on Attar's path of enlightenment, even if he has some qualities defined by Fromm and humanistic psychologists, knows the goal that he wants to develop and possesses the perception of the oneness of existence, namely that there 
is no other existence from God. Unity in the oneness of existence is in knowing. This knowledge is obtained with pleasure and is known by being alive (Cebecioğlu, 2005, p. 281). One is not alone existentially. It provides a spiritual relationship with God, who manifested everything from His Self. The human craving is the maturation of human cravings. Anymore, he is the nafs matured. As a Sufi, one has obtained the features of total maturity and has passed to a state of enlightenment. In a way, this can be called the cravings of the holy, of the pure, and of the astute (Cebecioğlu, 2005, p. 199). Those who have entered through the cravings that command and take pleasure in evil (Nafs-i Emmare) have arrived at the stage of cravings matured (Nafs-i Kamil). In this way, it is not a change in human nature but a change in ideas, morals, and behaviors. Life follows a new path as a style, thought, and behavior. Thus, an improvement and beautification is seen in the nafs, and hence, in the person. This improvement shows itself in actions as much as it does in thought (Altuntaş, 1986, p. 51).

\section{Conclusion}

The views of Attar, which have not diminished even with the passing of centuries, preserve their presence as a rich resource for us. It has appeared this way, this rich resource, and it will continue to sustain its presence from its value for hundreds of years more before losing anything. This is because his works are about humans and their universal essence. People of every century will be able to find their self in it.

In the explanations today's world of psychology have made about human psychology, it would be greatly lacking to not use what human culture has brought into being by accumulation or the amassed knowledge embodied in works that skilled individuals have woven by hand, such as Attar. The contents of this article were composed based on this idea.

According to Attar, while being patient and unselfish in delivering a person to their desires empowers a person through reassurance, internal motivation, and raised awareness, as well as strengthens solutions by dividing one's problems into smaller pieces, being angry and doing before thinking about the end will adversely affect the instrument from becoming purposeful.

In love/affection, while it is possible to arrive at love if one is devoted, diligent, cautious, and caring, becoming obsessed with lust distances one from love. Selfcontrol and self-sufficiency are good for one who wants to enhance their skills and knowledge if they are aware of their talents; if one can identify goals according to one's skills and is able to accept their lack of skills, they can be successful. Conversely, one who uses their knowledge as a power has now become its slave. In detachment, it is effort, acceptance, and thankfulness that turn to the core self; in unity, it is soft- 
headedness and solitude that do this, both while strengthening the person of equality; arrogance distances the person from finding the self. In the Valley of Astonishment and Bewilderment, there is admiration, generosity, feeling respect for everything outside of the self, acceptance of differences, re-existence, and solitude; in the Valley of Death, there is inner peace.

Attar emphasized the need to not empty the interior of words by saying "Its meaning left, its word remained." This article attempted to interpret from a psychological perspective the character traits, life style, and cognitive processes that want to lead us by taking the road based on the ideas of finding one's Truth and being oneness, while trying to remain within the understanding of the existential journey of Sufism. While making these interpretations, care was taken to not lose the meaning of the words.

\section{References}

Adler, A. (2002). Psikolojik aktivite üstünlük duygusu ve toplumsal ilgi [Superiority and social interest] (B. Çorakçı, Trans.). İstanbul, Turkey: Say Yayınları.

Adler, A. (2003). İnsan tabiatını tanıma [Understanding human nature] (A. Yörükân, Trans.). İstanbul, Turkey: Türkiye İş Bankası Yayınları.

Altıntaş, H. (1986). Tasavvuf tarihi [History of Sufism]. Ankara, Turkey: Ankara Üniversitesi Basımevi.

Aşkar, M. (2012). Feridüddin-i Attar'ın tasavvuf anlayışı [Attar's analysis of Sufism]. Bişkek Araşan Sosyal Bilimler Enstitüsü Ilmi Dergisi, 13, 5-10.

Attar, F. (2003). Esrarname [Book of mysteries] (M. Kanar, Trans.). İstanbul, Turkey: Ayrıntı Yayınları.

Attar, F. (2015a). Mantık al-tayr [Conference of birds] (A. Gölpınarlı, Trans.). İstanbul, Turkey: Türkiye İş Bankası Yayınları.

Attar, F. (2015b). İlâhiname [Book of God] (A. Gölpınarlı, Trans.). İstanbul, Turkey: Türkiye İş Bankası Yayınları.

Burger, J. M. (2006). Kişilik [Personality]. İstanbul, Turkey: Kaknüs Yayınları.

Cain, D. J. (2014). Birey odakl psikoterapiler [Individually focused psychotherapies] (N. Hamilton, Trans.). İstanbul, Turkey: Okuyan Us Yayınları.

Cebecioğlu, E. (2005). Tasavvuf terimleri ve deyimleri sözlüğü [Glossary of Sufi terms and expressions]. İstanbul, Turkey: Anka Yayınları.

Coşan, E. (1994). Íslam sevgi ve tasavvuf [Love of Islam and Sufism]. İstanbul, Turkey: Seha Neşriyat.

Corey, G. (2008). Psikolojik danışma, psikoterapi kuram ve uygulamaları [Psychological counseling, psychotherapeutic theory and practices] (T. Ergene, Trans.). Ankara, Turkey: Mentis Yayıncilik. 
Cummins, P. (2006). The Tuesday group. In P. Cummins (Ed.), Working with anger: A constructivist approach (pp. 13-24). Hoboken, NJ: John Wiley \& Sons.

Dattilio, F. M. (2015). Bilişsel davranış̧̧ı çift ve aile terapisi klinisyenler için kapsamlı bir rehber [A comprehensive guide to cognitive behavioral couples and family therapy clinicians] ( $\mathrm{T}$. Özakkaş, Ed. \& Trans.). İstanbul, Turkey: Psikoterapi Enstitüsü Eğitim Yayınları.

Demirci, M. (1997). Hal [Condition]. In TDV İslam ansiklopedisi (Vol. 15). İstanbul, Turkey: Türkiye Diyanet Vakfi Yayınları.

Frankly, V. E. (1999). Duyulmayan anlam çığlığı [The unheard cry of meaning]. Ankara, Turkey: Öteki Yayınevi.

Fromm, E. (1995). Umut devrimi [Revolution of hope]. İstanbul, Turkey: Panel Yayınları.

Glasser, W. (2008). Treating mental health as a public health problem: A new leadership role for counselors. In K. Jordan (Ed.), The quick theory reference guide (pp. 155-166). Hauppauge, NY: Nova Science Publishers.

Gölpınarlı, A. (1969). 100 soruda tasavvuf [Sufism in 100 questions]. İstanbul, Turkey: Gerçek Yayınevi.

Greenglass, E. R. (2005). The expression and management of anger and hostility: Psychological implications. In C. Spielberg \& I. Sarason (Eds.), Stress and emotion anxiety, anger and curiosity (pp. 123-142). New York, NY: Routledge, Taylor, \& Francis Group.

Gülbal, S. (2014). Feridü'd-din Attar Nî̧saburi'nin mantıku't-tayr adlı eserinde seyr-ûu sülûk kavramı [The principle of enlightenment in Attar's Mantiq ut-Tayr]. III. Türkiye Lisansüstü Çalışmalar Kongresi’nde sunulan bildiri. Sakarya Üniversitesi, Sakarya, Turkey.

Köroğlu, E. (2011). Bilişsel-davranış̧̧ psikoterapiler; Temel kavramlar, temel yaklaşımlar [Cognitive behavioral psychotherapy: Basic concepts, basic approaches]. Ankara, Turkey: HYB Yayıncilik.

Nichols, M. P. (2013). Aile terapisi kavramlar ve yöntemler [Family therapy concepts and methods] (O. Gündüz, Trans.). İstanbul, Turkey: Kaknüs Yayınları.

Öngören, R. (2009). Sufi. TDV Íslam ansiklopedisi (Vol. 37). İstanbul, Turkey: Türkiye Diyanet Vakfi Yayınları.

Öngören, R. (2011). Tasavvuf [Sufism]. TDV İslam ansiklopedisi (Vol. 40). İstanbul, Turkey: Türkiye Diyanet Vakfı Yayınları.

Perls, F. S., Hefferline, R., \& Goodman, P. (2000). Gestalt terapisi, içimizdeki çocuk [Gestalt therapy: The child within us] (N. Erkmen, Trans.). İstanbul, Turkey: Söz Yayın.

Sevgi, H. A. (2000). İlâhiname [Book of God]. TDV Íslam ansiklopedisi (Vol. 22). İstanbul, Turkey: Türkiye Diyanet Vakfı Yayınları.

Sevgi, H. A. (2003). Mantıku' t-Tayr [Conference of birds]. TDV Íslam ansiklopedisi (Vol. 28). İstanbul, Turkey: Türkiye Diyanet Vakfı Yayınları.

Schneider, K. J., \& Krug, O. T. (2015). Varoluşçu-hümanistik terapi [Existential-humanistic theory] (G. Akkaya, Trans.). İstanbul, Turkey: Okuyan Us Yayınları.

Smith, M. (1932). The Persian mystics: Attar. New York, NY: E. P. Dutton \& Company, Inc.

Stone, L. (2006). The topos of hayrat in Attar's mantig al-tayr. In L. Lewisohn and C. Shackle (Eds.), Attar and the Persian Sufi tradition: The art of spiritual flight. London, UK: I. B. Tauris. 
Şahinoğlu, N. M. (1991). Feridüddin Attar. TDV İslam Ansiklopedisi (Vol. 4). İstanbul, Turkey: Türkiye Diyanet Vakfı Yayınları.

Topaloplu, A. (2003). Materyalizm [Materialism]. TDV İslam ansiklopedisi (Vol. 28). İstanbul, Turkey: Türkiye Diyanet Vakfı Yayınları.

Türer, O. (2001). Tasavvufî düşüncede insan [Human, in Sufi thought]. Illmi ve Akademik Araştırma Dergisi, 5(2), 9-15.

Türkçapar, H. (2012). Bilişsel terapi: Temel ilkeler ve uygulama [Cognitive therapy: Basic principles and application]. Ankara, Turkey: HYB Basım Yayın.

Uludağ, S. (2006). Nefis [Human cravings]. TDV İslam ansiklopedisi (Vol. 32). İstanbul, Turkey: Türkiye Diyanet Vakfı Yayınları.

Yalom, I. (2000). Varoluşçu psikoterapi [Existential psychotherapy] (Z. Babayiğit, Trans.). İstanbul, Turkey: Kabalc1 yayınevi.

Young, J. E., \& Klosko, J. S. (2015). Hayatı yeniden keşfedin [Rediscovering life]. İstanbul, Turkey: Psikonet Yayınları. 